\title{
Burial dating of fluvial terraces using cosmogenic nuclides, Arieş River
}

\author{
Maria Hosu \\ Faculty of Geography, \\ Babeş-Bolyai University, \\ Str. Clinicilor Nr. 5-7, 400006, România \\ maria.hosu@ubbcluj.ro
}

\author{
Delia M. Gheorghiu \\ CIAF-NERC, \\ Scottish Universities Environmental Research Centre, \\ East Kilbride, \\ Glasgow, U.K
}

\author{
Sheng $\mathrm{Xu}$ \\ AMS, \\ Scottish Universities Environmental Research Centre, \\ East Kilbride, \\ Glasgow, U.K
}

\begin{abstract}
Dating of the fluvial terraces and providing a morphochronological picture has always been part of a controversial scientific debate, both locally and globally. The rivers in the Transylvanian Basin were studied between 1960 and 1980 and mainly focused on the number of teracces, the timing of river incision and how these terraces are represented in a palaeoreconstruction framework. In most cases, these studies were based on sedimentology, palynology, palaeontology, and archeology, but their chronological history has never been established. Surface exposure dating using the 10Be and $26 \mathrm{Al}$ cosmogenic nuclides would be an ideal dating method; however, river terrace deposits are made of individual clasts, each with their unique complex history of an initial exposure during exhumation and fluvial transport and then burial. This study is based on the numerical dating of the River Arieş terraces in the Corneşti Plăieşti area using the cosmogenic burial dating method. The morphological features of the study area were initially mapped in the field using topographical maps (1:25 000), geological maps (1:50,000), and orthophotographs $(50 \mathrm{~cm}$ resolution). The cosmogenic samples were collected from three different terraces from depths down to 12-15 $\mathrm{m}$ from newly excavated parts within the study area. The 10Be and 26Al burial dating of these river terraces yields palaeoincision rates in the upper basin during the terraces deposition, provides age estimates for these deposits and further argues for the role of climate and tectonics in the deposition and subsequent incision of the terraces.
\end{abstract}

Keywords - fluvial terraces; cosmogenic nuclides; burial dating; Romania; Arieş

\section{INTRODUCTION}

In the River Arieş basin, the terraces have been studied since 1912 [1] when the existence and the extent of terraces steps were firstly discussed, both in a transversal and longitudinal river profile. Subsequent research studies
[2] [3] [4] [5] noted the number of river terraces and their altitudinal distribution, the structure and the hydrogeological observations made on the terraces for determining the level of the water table. Most of these studies were made by geomorphological mapping on certain sectors, with extrapolations for the entire transversal and longitudinal profile of the river.

Our study area is located in the lower sector of the River Arieş (Fig. 1) where six levels of terraces were identified. The size of the terraces differ from one place to another based on the genesis and the morphological and tectonic context of this area. The transversal profile in the lower part of the river is asymmetric.

In this study we present numerical ages obtained from sediment samples taken from several terraces in the study area. Cosmogenic burial dating is a method based on the radioactive decay rates of cosmogenic nuclides. This method requires the sample to be completely shielded after the initial exposure [6]. We employ the burial-dating method to calculate the time since deposition of the terraces, the palaeo-erosion rates in the basin at time of deposition of these terraces, and the rates of erosion since deposition. This study introduces the first application of the cosmogenic burial method to terraces in Romania.

\section{GEOMORPHOLOGY}

The River Arieş drains the following units within its basin: the Bihor Mountains located in the western part of the basin; the Gilău-Muntele Mare Mountains in the central and north-central part; the Metaliferi and Trascău Mountains in the south and south-east and the Feleac Hills in the north-eastern part. 
The Arieş basin spreads over $3005 \mathrm{~km}^{2}$, between 1108 $\mathrm{m}$ and $264 \mathrm{~m}$ altitude, and has a mean altitude of $818 \mathrm{~m}$. The river is $166 \mathrm{~km}$ long and has a mean gradient of 5\% and a sinuosity coefficient of 1.71 [7].

Before exiting the mountain area, the River Arieş cut a deep gorge in limestone and magmatic rocks (Mesozoic magmatites). Downstream of this sector, the morpho hydrographic character of the river changes when flowing through the more friable sedimentary rocks of Miocene age (clays and marls). The influence of petrography caused the River Arieş to create a basin type corridor at the meeting point between the Apuseni Mountains and the Transylvanian Basin, a corridor which becomes larger towards the confluence with the River Mureş. Furthermore, the sudden change of the geological deposits generally explains the slope modifications of the River Arieş: 3.3\%o in the Moldoveneşti-Mihai Viteazu sector; 2.9\%o in the Mihai Viteazu-Turda sector; $1.86 \%$ in Turda-Poiana sector and $0.33 \%$ in Poiana - River Mureş sector [2].

Our study area is mainly focused on the fluvial terraces in the lower sector of the River Aries (Fig. 1). Here the terraces are stepped, and mostly asymmetrical on the right side of the river. The thickness of the alluvial sand and gravel within the structure of the terraces $(7-15 \mathrm{~m})$ is thought to have formed through local subsidence, probably as a result of uplift due to diapirism. This subsidence process associated with the general south-east tilting of the geological strata influenced the monolateral formation of the fluvial terraces and the permanent erosion tendency of the River Arieş on the left side.

According to past research, in the lower sector of the River Aries, the fluvial terraces have various extents and altitudes above river level, depending on their position in the longitudinal profile, which means that the relative altitude of the terraces decreases towards the River Mureş.

Previous research studies identified the following terrace sequence: the floodplain terrace with two levels (2$3 \mathrm{~m}$ and 4-6 m); the 10-12 $\mathrm{m}$ terrace, covered in diluvium, has an inclined surface which makes it difficult to delimit it from the lower terrace; the 20-25 m terrace has a maximum extent downstream and becomes narrower upstream; the 35-40 $\mathrm{m}$ terrace is formed throughout the entire longitudinal profile of the valley; the 50-55 m terrace is the most extended and it is present throughout the entire longitudinal profile of the valley, between the gorge at Buru-Moldovenesti and the confluence with the River Mureş; the 70-75 m terrace was identified on the left part of the river as fragments only [2].

\section{METhODS AND RESUltS}

The fluvial terraces in our study area were identified on topographical maps (1:25 000), and most were later checked in the field. Several methods were used to measure terraces heights.

For the relative altitude we calculated the difference between the absolute altitude of the River Aries bed and the absolute altitude of the terraces level on the same alignment. The altitude of few terraces was directly measured on the topographical map $(1: 25,000)$ and the following terraces were identified: the 4-6 m terrace, downstream of the Corneşti town; the 10-12 m terrace, found to be heavily covered in proluvial deposits; the 35$40 \mathrm{~m}$ terrace is the most extensive terrace having an almost horizontal surface; the 50-55 m terrace, well developed in the Moldoveneşti - Bădeni sector.

Subsequent extensive quarrying of sand and gravel in the Bădeni area (where samples AR03, AR04, AR05, AR06, AR07, 08 were collected) the initial topographic surface was significantly modified at the contact between the 35-40 m terrace and the 50-55 m terrace. Moreover, the surface of the 50-55 terrace was eroded by the tributaries of the River Arieş (the Plăieşti and the Bădeni streams). The transition between these two terraces was identified on orthophotoplans (1:5000, year 2005, $50 \mathrm{~cm}$ resolution, $\pm 1.5 \mathrm{~m}$ precision).

Samples for cosmogenic analysis were collected from profiles previously made by quarrying of sand and gravel (ballast). We collected 2 samples from the 10-12 m terrace, four samples from the $35-40 \mathrm{~m}$ terrace, and two samples from the 50-55 m terrace (Fig. 1). Samples were selected from various depths, down to $15 \mathrm{~m}$ below the surface level.

The processing of the 8 samples was entirely performed at the Cosmogenic Isotope Analysis Facility in SUERC (Scottish Universities Environmental Research Centre) in East Kilbride (Glasgow). Samples were crushed and wet sieved and quartz was separated from the other minerals through various mechanical and chemical processes. Be and $\mathrm{Al}$ were further isolated through column chromatography. The samples were subsequently measured by Accelerator Mass Spectrometry) at SUERC.

The calculated 10Be and 26Al concentrations were modeled using a computer algebra system. This model shows a complex exposure-burial history of these terrace deposits, with periods of initial exposure, transport and burial of sediments and subsequent periods of erosion of these sediments combined with deposition.

The model used in this study provides minimum ages for the deposition of the terraces in the lower sector of the River Arieş (up to $1.7 \mathrm{Ma}$ ). The terraces may well be the result of older reworked alluvial deposits, revealing a complex transportation history from the higher up source area. This is well supported by the variety of erosion rates in the Arieş basin (20-150 m/Ma), also suggesting that tectonics and climate had both an important role in the fluvial processes that occurred in this area.

\section{CONCLUSIONS}

The burial dating model allows to calculate minimum ages of the deposits using paired cosmogenic nuclides and gives an understanding of the sedimentological history at the time of terraces deposition. This method has applicability in various environments for understanding the past climate and tectonics. Our study suggest that the terraces were formed during the Quaternary period and it is a major contribution to a growing dataset for the Carpathians region. 


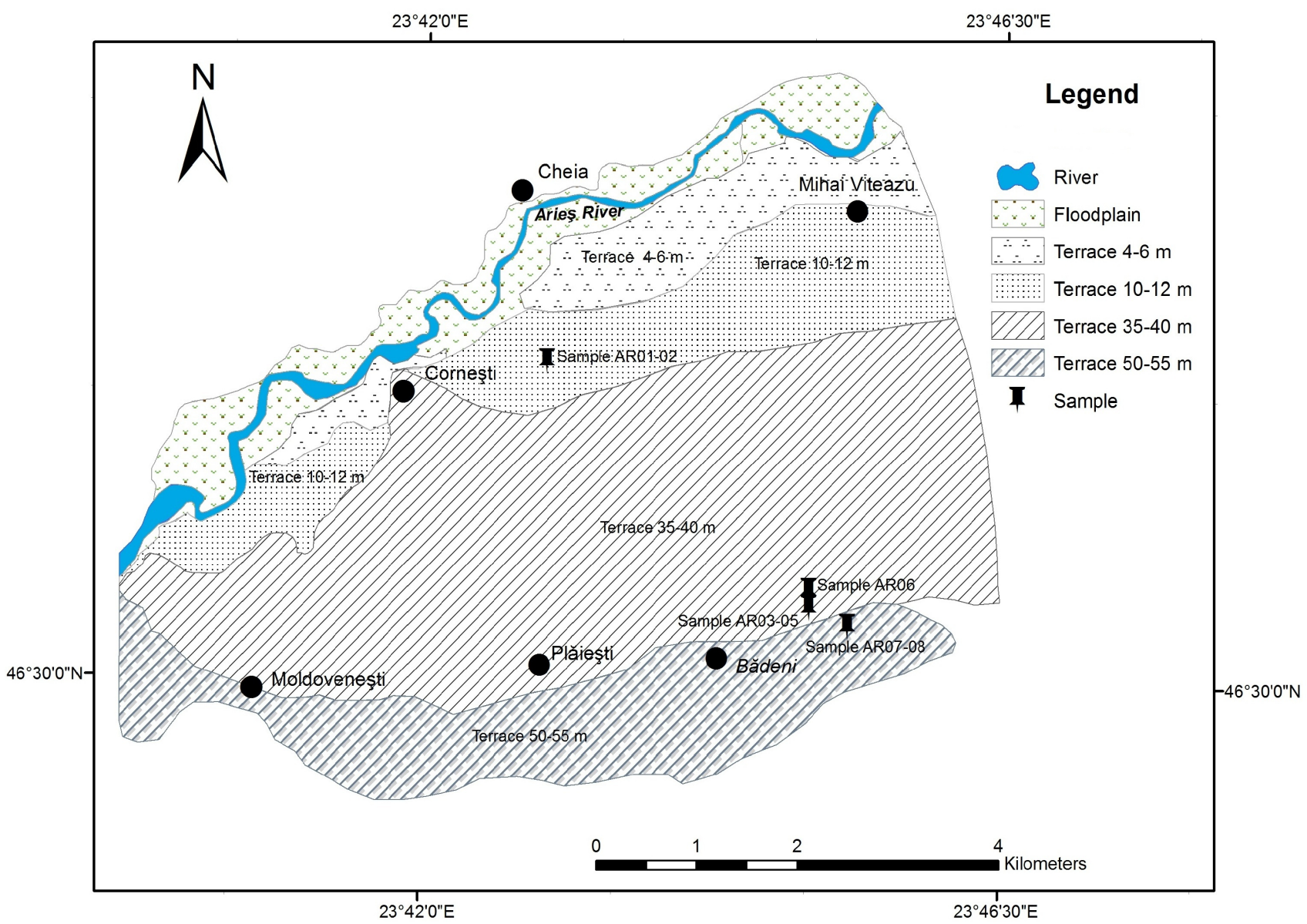

Fig. 1. Study area in the lower sector of the River Arieş. Geomorphological map. Location of samples collected.

\section{ACKNOWLEDGMENT}

The authors are grateful to the Cosmogenic Isotope Analysis Facility and Accelerator Mass Spectrometry Facility at SUERC for the sample preparation and measurement.

\section{REFERENCES}

[1] L. Sawicki, Beitrage zur morphologie Siebenburgen, 1912, manuscris. (in German)

[2] T. Morariu and D. Iacob, "Câteva observații hidrogeologice în bazinul inferior al Arieşului”, Studia Universitatum Victor Babeş et Bolyai, III, 5, seria II, Geologie-Geographia, Cluj-Napoca, 1958. (in Romanian)
[3] T. Morariu and V. Gârbacea, "Terasele râurilor din Translvania”, Comunicări ale Academiei Române, vol. X, nr.6, Bucuresti, 1960. (in Romanian)

[4] Al. Savu, I. Mac, and P. Tudoran, "Aspecte privind geneza şi vârsta teraselor din Transilvania”, in Realizări în geografia României, Culegere de studii, ed. Ştiinţifică. Bucuresti, 1973. (in Romanian)

[5] Gr. Pop, Depresiunea Transilvaniei, Edit. Presa Universitara Clujană, Cluj-Napoca, 2001. (in Romanian)

[6] G. Balco and C.W. Rovey II, "An isochron method for cosmogenic-nuclide dating of buried soils and sediments", American Journal of Science, vol. 308, no. 10, pp. 1083-1114, 2008.

[7] Atlasul Cadastrului Apelor din România, Ministerul Mediului. Partea 1. Date morfo-hidrografice asupra reţelei hidrografice de suprafaţă, Bucureşti, 1992. (in Romanian) 